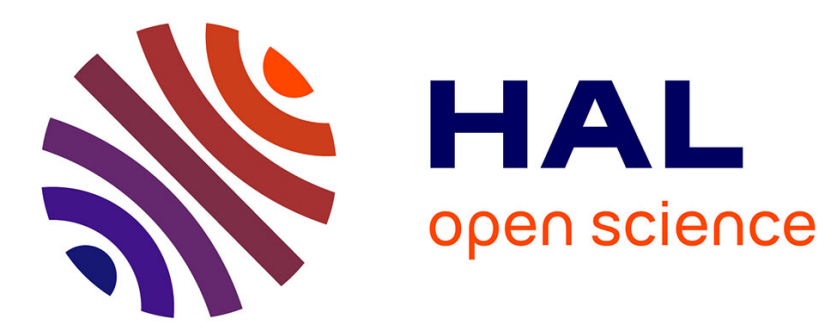

\title{
Genetic variation of natural durability traits in Eucalyptus cladocalyx (sugar gum)
}

Bush, Mccarthy, Meder

\section{To cite this version:}

Bush, Mccarthy, Meder. Genetic variation of natural durability traits in Eucalyptus cladocalyx (sugar gum). Annals of Forest Science, 2011, 68 (6), pp.1057-1066. 10.1007/s13595-011-0121-z . hal00930691

\section{HAL Id: hal-00930691 \\ https://hal.science/hal-00930691}

Submitted on 1 Jan 2011

HAL is a multi-disciplinary open access archive for the deposit and dissemination of scientific research documents, whether they are published or not. The documents may come from teaching and research institutions in France or abroad, or from public or private research centers.
L'archive ouverte pluridisciplinaire HAL, est destinée au dépôt et à la diffusion de documents scientifiques de niveau recherche, publiés ou non, émanant des établissements d'enseignement et de recherche français ou étrangers, des laboratoires publics ou privés. 


\title{
Genetic variation of natural durability traits in Eucalyptus cladocalyx (sugar gum)
}

\author{
David Bush $\cdot$ Kevin McCarthy $\cdot$ Roger Meder
}

Received: 6 December 2010 / Accepted: 10 May 2011 /Published online: 25 August 2011

(C) INRA and Springer Science+Business Media B.V. 2011

\begin{abstract}
- Introduction We present a study on genetic variation in natural durability traits of young-aged Eucalyptus cladocalyx, a species adapted to temperate, low rainfall regions. Our motivation was the production of naturally durable posts for applications such as vine trellises, a sector dominated by heavy metal preservative-treated wood in some of the world's main wine-producing countries.

- Methods Stem diameter at breast height over- and underbark, heartwood proportion, wood density, methanol extractives and fungal decay were assessed in a progeny test on a set of 48 families from eight provenances nested within three regions of provenance (ROP) from the species'
\end{abstract}

\section{Handling Editor: Christophe Plomion}

Electronic supplementary material The online version of this article (doi:10.1007/s13595-011-0121-z) contains supplementary material, which is available to authorized users.

\section{Bush $(\bowtie)$}

Division of Plant Industry, Commonwealth Scientific and Industrial Research Organisation (CSIRO),

CSIRO Black Mountain Laboratories, Clunies Ross Street,

Black Mountain,

Canberra, ACT, Australia

e-mail: david.bush@csiro.au

\section{K. McCarthy}

Division of Materials Science and Engineering, Commonwealth

Scientific and Industrial Research Organisation (CSIRO),

Gate 5 Normanby Road,

Clayton, VIC 3168, Australia

\section{R. Meder}

Division of Plant Industry, Commonwealth Scientific and Industrial Research Organisation (CSIRO),

St. Lucia Bioscience Precinct 306 Carmody Road,

ST. LUCIA, QLD 4067, Australia

D. Bush

Australian National University,

Canberra, Australia natural range. Near-infrared reflectance (NIR) was examined as an efficient assessment method.

- Results Strong variation among ROP was indicated for all traits, with low-moderate narrow-sense heritability for growth traits and extractives content and moderate-high heritability of basic density and decay resistance to two of the three fungi. Trait-trait correlations ranged from low to high, with basic density and extractives content being negatively correlated to decay mass loss.

- Discussion NIR was an effective predictor of methanol extractives, moderately effective for basic density, but unsuccessful for fungal decay. Generally, there were no practically adverse correlations between growth and durability traits.

- Conclusion Substantial genetic variation in natural durability traits is indicated, with wide scope for genetic improvement.

Keywords Natural durability Eucalyptus cladocalyx $\cdot$ Near infrared reflectance. Genetic variation

\section{Introduction}

Natural durability is a wood property allowing it to resist biodeterioration caused by bacteria, fungi, termites, borers and marine organisms without treatments of preservative chemicals or coatings. Certain species are highly resistant to biodeterioration and are recommended for use in untreated applications, whilst others are known to be highly susceptible. Natural durability is increasingly regarded as a desirable wood property obviating the need for costly and potentially harmful chemical preservative treatments. This study was motivated by the desire to produce untreated vineyard trellis posts. In Australia, Chile, New Zealand and South Africa, copper/ chrome/arsenate-treated softwood posts are typically used: untreated softwood is not sufficiently durable to last the 25 years in-ground that is required of a vineyard post. Similarly motivated research is also underway in Europe to 
examine the natural durability of eucalypts suited to Mediterranean climates (Lorenzo et al. 2007; Palanti et al. 2010) and softwood species for use in durable applications.

There is often significant diversity in resistance to biodeterioration within species (Hillis 1987), and a component of this variation may be genetic and possibly amenable to improvement through tree breeding. Genetic variation in natural durability traits has been studied for a number of taxa including Larix spp. (reviewed by Gierlinger et al. 2004), Picea glauca (Yu et al. 2003), Pinus sylvestris (e.g. Ericsson and Fries 1999), Pinus taeda (Schmidtling and Amburgey 1982), Quercus spp. (Mosedale et al. 1996) and Tectona grandis (Kjaer et al. 1999). Until recently, Eucalyptus species, which are very variable in their natural durability properties (Rudman 1966), have been relatively unstudied except in relation to heartwood/sapwood ratio (e.g. Nicholls and Matheson 1980; dos Santos et al. 2004) and extractive content (Washusen et al. 2001; Poke et al. 2006), the latter usually in connection with species suited to pulping. Recently, Palanti et al. (2010) found significant variation in fungal decay resistance among a small number of $E$. grandis and Eucalyptus camaldulensis $\times$ botryoides clones.

Standards Australia (2005) assigns durability ratings for timbers in aboveground, in-ground and marine applications based upon the resistance of the outer heartwood of mature timbers. The sapwood of all species is considered nondurable, and for many, including the eucalypts, the inner heartwood and pith is also of lower durability than the outer heartwood (Rudman 1966). The Standard lists the in-ground durability of numerous Eucalyptus species commonly used for building and construction as well as non-Australian species. Timbers are assigned to one of four classes: class 1 , where timber remains sound in-ground for greater than 25 years, e.g. T. grandis; class 2, 15-25 years, e.g. E. camaldulensis; class 3, 5-15 years, e.g. Thuja plicata, E. globulus; and class 4, 0-5 years, e.g. Pinus radiata, Pseudotsuga menziesii.

Amongst the more durable eucalypt species is Eucalyptus cladocalyx F. Muell. (sugar gum), with in-ground durability recently reclassified from class 2 to class 1 (Standards Australia 2005). It is an open-forest and woodland species endemic to South Australia. A breeding programme has commenced in Australia because of its suitability for low rainfall sites where it might be planted for the production of timber and poles as well as for environmental remediation (Harwood et al. 2007); it is also being genetically improved in Chile (Mora et al. 2009). It occurs in three geographically disjunct regions, two situated in mainland Australia and one on Kangaroo Island (see Table 1 for geographic coordinates). Clustering of three subpopulations or regions of provenance (ROP) within the species corresponding to these regions has been demonstrated using allozyme markers (McDonald et al. 2003), and Callister et al. (2008) demonstrated that growth and form traits are broadly similar among provenances within regions. It was formerly used in exposed applications requiring high strength and durability such as bridge and railway timbers, though its use declined after the 1940s with the widespread availability of low-cost copper/chrome/ arsenate-treated $P$. radiata timber and other materials.

The factors responsible for the differences in durability among and within species are numerous and diverse. Highdensity timbers have a relatively low void volume which may inhibit permeation of gases and liquids, though within-species correlation between density and decay resistance has been shown not only to be sometimes positive (e.g. in Eucalyptus delegetensis; Wong et al. 1983) but also absent or negative in other species (see Yu et al. 2003). The most important factor is the presence of extractives, the quality and quantity of which both influence durability. Toxic polyphenolic extractives act as chemical barriers (e.g. Mohareb et al. 2010) and tyloses act as physical barriers limiting access to the transpiration system (Beckman 2000). The amount of extractives has been shown to be correlated with decay resistance in both softwoods (e.g. Gierlinger et al. 2004) and hardwoods including eucalypts (Wong et al. 1983). An axial core of extractives is deposited as sapwood is transformed into heartwood, and it is therefore only the heartwood of 'durable' species that are actually durable. It is this part of the wood that would be used in pole production.

This study examined the genetic variation in the durability properties of E. cladocalyx using samples taken from a common-garden, provenance-progeny trial situated at Benalla, Victoria. We have examined durability-related traits including heartwood/sapwood ratio, heartwood extractive content and resistance to biodeterioration from three soil fungi. We also investigated the use of nearinfrared reflectance (NIR) to rapidly and cost-effectively screen samples for these traits.

\section{Materials and methods}

\subsection{Sample population and procedures}

Data and samples were collected in August 2006 from an $E$. cladocalyx provenance-progeny trial situated at Benalla, Victoria, established in 1998. The site is temperate (KöppenGeiger $\mathrm{Cfb}$ ), receiving 720-mm mean annual rainfall. All families included (Table 1) were collected by the Australian Tree Seed Centre (ATSC) as representative random samples from wild populations. The trial incorporates 73 families from seven provenances that came from three regions of provenance defined by the findings of McDonald et al. (2003): South Flinders Ranges, Eyre Peninsula and Kangaroo Island.

The trial was established as four replicates of five-tree row plots in randomised complete blocks. An additional four replicates of randomised five-tree plots including a subset of families were also established. The trial was planted at a 
Table 1 Composition and sampling detail of the 8-year-old E. cladocalyx provenance-progeny trial at Benalla, Victoria

\begin{tabular}{|c|c|c|c|c|c|c|}
\hline $\begin{array}{l}\text { Regions of provenance } \\
\text { and provenance }\end{array}$ & ATSC seed lot no. & Latitude & Longitude & No. of families in trial & Families sampled & Samples taken (trees) \\
\hline \multicolumn{7}{|l|}{ South Flinders Ranges } \\
\hline $6.7 \mathrm{~km}$ NE Wirrabara Forest & 16013 & $33^{\circ} 02^{\prime} \mathrm{S}$ & $138^{\circ} 12^{\prime} \mathrm{E}$ & 11 & 6 & 26 \\
\hline Wilmington & 19348 & $32^{\circ} 42^{\prime} \mathrm{S}$ & $138^{\circ} 06^{\prime} \mathrm{E}$ & 10 & 7 & 35 \\
\hline $9 \mathrm{~km} \mathrm{~S}$ Wilmington & 16089 & $32^{\circ} 43^{\prime} \mathrm{S}$ & $138^{\circ} 06^{\prime} \mathrm{E}$ & 10 & 10 & 48 \\
\hline \multicolumn{7}{|l|}{ Eyre Peninsula } \\
\hline Marble Range & 19349 & $34^{\circ} 30^{\prime} \mathrm{S}$ & $135^{\circ} 31^{\prime} \mathrm{E}$ & 10 & 5 & 21 \\
\hline $6.1 \mathrm{~km}$ ESE Wanilla & 16018 & $34^{\circ} 33^{\prime} \mathrm{S}$ & $135^{\circ} 44^{\prime} \mathrm{E}$ & 10 & 5 & 20 \\
\hline \multicolumn{7}{|c|}{ Kangaroo Island, South Australia } \\
\hline Flinders Chase National Park 1 & 16022 & $35^{\circ} 45^{\prime} \mathrm{S}$ & $136^{\circ} 38^{\prime} \mathrm{E}$ & 12 & 11 & 55 \\
\hline Flinders Chase National Park 2 & 19717 & $35^{\circ} 57^{\prime} \mathrm{S}$ & $136^{\circ} 44^{\prime} \mathrm{E}$ & 10 & 5 & 21 \\
\hline Total & 7 & & & 73 & 49 & 226 \\
\hline
\end{tabular}

density of 1,235 stems per hectare. The diameter of all trees in the trial $(n=1,440)$ was measured in August 2006, at which time the trial was unthinned. It is estimated that the trial had reached the canopy closure stage in circa 2003.

Families were selected for wood property sampling on the basis of their diameter growth ranking, with larger-diameter families ranking highest. Trees were preferentially selected within families on the basis of potential suitability (sufficient diameter and straightness to a height of $3 \mathrm{~m}$ where possible) for a vineyard post at the time of sampling. As this trial was based entirely on unselected, unimproved material, it was not always possible to find enough trees with these characteristics, and so trees having sufficient diameter but not stem straightness were selected in some cases.

\subsection{Coring}

Two 12-mm diameter, bark-to-bark cores were removed from each tree at breast height. All cores were taken from the same (north-south) orientation, and the northern end was marked on each core along with the individual tree identity.

\subsection{Heartwood-sapwood boundary definition and proportion}

One core from each pair was stained along its length with dimethyl yellow, a pH indicator that can be used to sharply delineate the heartwood-sapwood boundary of eucalypts (Hillis 1987). The heartwood boundary was traced from the stained core to the unstained core. The core sapwood and heartwood lengths were measured to give heartwood and sapwood proportions of total diameter at breast height under bark (DBHUB). Diameter at breast height over bark (DBHOB) was determined in the field using a diameter tape, and bark diameter and thickness was determined by subtracting DBHUB from DBHOB of the cored stem.

\subsection{NIR spectroscopy and model calibration}

Due to the high cost of extractive and accelerated biodeterioration analysis, NIR was investigated as a potential measurement tool. NIR can be highly effective for determining extractive content in particular (e.g. Bailleres et al. 2002; Poke et al. 2005). The NIR spectra for each sample were obtained from wood meal produced by grinding with coarse then fine Wiley Mill screens (200- $\mu \mathrm{m}$ final granule size) heartwood portions of a sample of the second, unstained set of cores. Wood meal was contained in a quartz vial and spectra acquired using the integrating sphere on a Bruker MPA (Bruker Optics, Ettlingen, Germany; www.brukeroptics. com). Spectra were acquired between 10,000 and $4,000 \mathrm{~cm}^{-1}(1,000-2,500 \mathrm{~nm})$ at $8-\mathrm{cm}^{-1}$ spectral resolution. Multivariate calibration was performed for each of the wood traits using The Unscrambler v9.8 (www.camo.com).

\subsection{Basic density}

Stained cores were soaked in water for $24 \mathrm{~h}$ to achieve fibre saturation. Each core was then partitioned into three sections, two sections of sapwood and the heartwood. The volume of each core section was then accurately determined by the water displacement method (TAPPI 1989). The core segments were then oven-dried at $103 \pm 1^{\circ} \mathrm{C}$ for $24 \mathrm{~h}$ and weighed. Basic density for the sapwood and heartwood of each tree's core sample was determined as the oven-dried weight divided by the volume for each segment.

\subsection{Accelerated biodeterioration}

Following basic density determination, the stained heartwood segments were prepared for accelerated decay testing. Prior to exposure to decay fungi, specimens were sterilized by gamma $(\gamma)$ irradiation. Fungal strains are denoted by the 
DFP strain number (National Herbarium of Victoria, MEL). Three fungi, two brown rot (Gloeophyllum abietinum [13851] and Fomitopsis lilacino-gilva [1109]) and one white rot (Perenniporia tephropora [7904]) were used to evaluate the core specimens. Glass jars $(250 \mathrm{ml})$ were filled with $136 \mathrm{~g}$ fresh, damp soil and moistened with $14 \mathrm{ml}$ to $100 \%$ water holding capacity. One poplar sapwood veneer feeder strip $(40 \times 45 \times 2 \mathrm{~mm})$, which had been soaked to saturation in $1 \%$ malt extract solution, was placed on top of the soil in each jar. Metal lids were used to close the jars which were then sterilized by autoclaving and allowed to cool. Feeder strips were introduced into the jars and inoculated with actively growing mycelium of the test fungi and incubated at $25^{\circ} \mathrm{C}$. When the feeder strips were fully colonized by the fungi, two sterile test specimens were placed on top. A replicate set of jars was left uninoculated as a sterile control. Specimens were also placed into these jars to determine any mass loss or gain not attributable to fungal attack. All jars were incubated at $25^{\circ} \mathrm{C}$ for 12 weeks. Specimens were removed from the jars and wiped of any adhering mycelium, then weighed to determine moisture content, and left to air dry for 12 days. Specimens were then dried in vacuum ovens at $40^{\circ} \mathrm{C}$ and $-95 \mathrm{kPa}$ for 5 days, weighed, adjusted to accommodate any changes recorded in the sterile controls, and the percentage mass losses determined.

\subsection{Extractive percentage weight determination}

Methanol extractives (percentage weight) were determined for a subset of 124 cores by the method described in Standards Australia (2003) to enable NIR calibration to be performed. Ground wood samples previously used in the NIR analysis were oven-dried at $103 \pm 1{ }^{\circ} \mathrm{C}$ for $24 \mathrm{~h}$ and placed in an airtight desiccator until cool. Once cool, 2.000 $\pm 0.100 \mathrm{~g}$ of wood granules from each sample was weighed into a cellulose extraction thimble. Each sample was placed in a Soxhlet apparatus charged with $180 \mathrm{ml}$ of methanol and extracted for $6 \mathrm{~h}$. The methanol extract was rotary evaporated under reduced pressure until approx. $5 \mathrm{ml}$ of extract remained. It was transferred to a watch glass of known weight and placed in an oven at $70^{\circ} \mathrm{C}$ for $12 \mathrm{~h}$ to fully evaporate the solvent. The watch glass was removed from the oven, allowed to cool in a desiccator and then weighed to determine the mass of extractive as a percentage of the heartwood mass.

\subsection{Statistical analysis}

Restricted maximum likelihood (REML) analysis of variance in each measured trait was carried out using a general linear mixed model of the form:

$y=\mathbf{X} b+\mathbf{Z} u+e$ where $\boldsymbol{y}$ is the vector of observations on $n$ traits, $\boldsymbol{b}$ and $\boldsymbol{u}$ are vectors of fixed and random effects, respectively, $\mathbf{X}$ and $\mathbf{Z}$ are incidence matrices for fixed and random model terms, and $\boldsymbol{e}$ is a vector of random residual terms. Variants of this model were applied as follows:

1. For estimation of significance of effects and effect means

The vector $\boldsymbol{b}$ (Eq. 1) contained sub-vectors for fixed effects of replicate, region of provenance, provenance and family effects, and $\boldsymbol{u}$ contained sub-vectors for the random effects of plots and incomplete blocks (rows and columns of trees superimposed within blocks) in the whole-trial DBHOB analysis. The incomplete block and plot terms were dropped from the analyses of traits where variance components were small, negative or with large standard errors. In practice, this was virtually all of the wood property traits. Wald tests were performed for fixed effects with approximate $F$ statistics and corresponding numbers of residual degrees of freedom as implemented in Genstat version 12 (VSN International, Hemel Hempstead, UK).

2. For estimation of variance components and functions

ASReml version 2.0 (VSN International) was used to estimate genetic variance components and heritability and calculate their standard errors using a first-order Taylor series expansion to approximate the variance of a ratio of variances. The heritability of each trait was estimated using univariate analyses and bivariate analyses estimated correlations between traits. Families were modelled as nested within provenances. Incomplete blocks and plots were modelled without covariance, whilst family effects and error were modelled with covariance to determine genetic correlations. Narrow-sense heritability (family within provenance) was estimated for each trait as:

$\widehat{h}^{2}=\frac{2.5 \sigma_{\mathrm{f}}^{2}}{\sigma_{\mathrm{f}}^{2}+\sigma_{\mathrm{e}}^{2}}$

where $\sigma_{\mathrm{f}}^{2}$ is the variance of half-sib families and $\sigma_{\mathrm{e}}^{2}$ is the error variance; 2.5 represents a coefficient of relationship $(\rho)$ of 0.4 , which appears to be suitable for this species given its relatively high levels of inbreeding (Bush et al. 2011). For the DBH trait, the plot variance component was also added to the denominator of Eq. 2.

\section{Results}

3.1 Diameter and heartwood proportion

The mean DBHOB of whole and core sample population stems ( $n=1,440$ and $n=222$, respectively) were 12.8 and 
$13.2 \mathrm{~cm}$, respectively. There were significant differences for this trait $(\mathrm{Fpr} .<0.001)$ between ROP, provenances and families within provenance for both sample populations (Table 2). The coefficient of phenotypic variation $\left(\mathrm{CV}_{\mathrm{P}}\right)$ of the whole-trial population was relatively lower for the selected trees (18\%) than for the whole population $(29 \%)$. The heritability estimate for the whole population was 0.26 $(\mathrm{SE}=0.08)$, but was significantly higher for the (biased) cored sample $0.59(\mathrm{SE}=0.08)$.

There were significant differences $(\mathrm{Fpr} .<0.001)$ at the ROP and family levels for bark thickness; South Flinders trees had significantly thicker bark than either Kangaroo Island or Eyre Peninsula (1.4>1.1 $\approx 0.9-\mathrm{cm}$ radial thickness, respectively), corresponding to $11-18 \%$ of DBHOB. There was no significant difference in heartwood and sapwood symmetry along the axis in the north-south directions in which the cores were taken.

There were significant differences $($ Fpr. $\leq 0.007)$ in heartwood diameter (expressed as proportions of both DBHOB and DBHUB) among ROP and families (nested within provenances within ROP), but not among provenances (Table 2). South Flinders Ranges provenances have significantly more heartwood as a percentage of DBH than the Kangaroo Island material and slightly more than the Eyre Peninsula provenances. Heritability (family within provenance) was estimated at 0.38 and 0.30 for heartwood percentage of DBHOB and DBHUB, respectively, with $\mathrm{CV}_{\mathrm{P}}=28 \%$ and $29 \%$, respectively. The mean heartwood DBH for the sampled trees was $72 \mathrm{~mm}$, with Kangaroo Island and South Flinders Ranges ROP having 58 and $82 \mathrm{~mm}$, respectively.

\subsection{Basic density}

Significant differences among ROP exist for heartwood, sapwood and whole-of-core basic density (BD; Fpr. $<0.001$ ), though the significance of the effect at the family level is higher for heartwood than sapwood. South Flinders Ranges material tended to be denser than Kangaroo Island and Eyre Peninsula. Sapwood was less dense $\left(640 \mathrm{~kg} \mathrm{~m}^{-3}\right)$ than heartwood $\left(670 \mathrm{~kg} \mathrm{~m}^{-3}\right)$ for all provenances, with mean wood BD $660 \mathrm{~kg} \mathrm{~m}^{-3}$. Heartwood BD was moderately heritable, $\widehat{h}^{2}=0.41(0.10)$, whereas sapwood BD was less so, $\widehat{h}^{2}=0.23(0.12)$. Phenotypic variation in this trait was low: $\mathrm{CV}_{\mathrm{P}}=5-6 \%$.

\subsection{Methanol extractives}

Mean methanol extractive content for the sample set was $12 \%$, with strong region-of-provenance and provenance differences (Fpr. $\leq 0.003$ ), but non-significant family-withinprovenance effects $(\mathrm{Fpr}=0.06)$. The South Flinders Ranges and Eyre Peninsula provenances had a much higher percentage of heartwood extractives than the Kangaroo Island provenances. Heritability was estimated at 0.25 and $\mathrm{CV}_{\mathrm{P}}$ is $23 \%$. All 11 of the Kangaroo Island families are ranked in the bottom 14 of 49 families, the lowest family mean extractive content being $6.3 \%$.

\subsection{Resistance to biodeterioration}

The mass loss results indicate differential responses of provenances to the three different fungi, though the overall, mass loss was low to moderate, with better families from the South Flinders Ranges having $<5 \%$ mass loss for all three fungi. The most aggressive fungus, F lilacino-gilva [1109], was a brown rot. The Kangaroo Island provenances were the least decay-resistant. Heritability estimates for $P$. tephropora [7904] and G. abietinum [13851] were high ( 0.52 and 0.58 , respectively), whilst the estimate for $F$. lilacino-gilva was low at 0.13 , with a high standard error (0.14). Whilst there was a large amount of variation among provenances for decay resistance to $F$. lilacino-gilva (appearing as a highly significant $F$ probability at the ROP stratum in Table 2), there is little family-withinprovenance variation.

\subsection{Phenotypic and genetic correlations}

Phenotypic $\left(r_{\mathrm{p}}\right)$ and genetic $\left(r_{\mathrm{G}}\right)$ correlations (Table 3) among the three fungal mass loss estimates were all positive, with $P$. tephropora [7904] having strong $r_{\mathrm{G}}$ with $F$ lilacino-gilva [1109] and G. abietinum [13851]. Though $r_{\mathrm{p}}$ between 1109 and 13851 was significant and moderate, $r_{\mathrm{G}}$ was lower than between the other two fungi and had a high standard error. Trait-trait correlations involving 1109 could not be determined in some cases and had high associated standard errors in others - variance was mainly partitioned at the provenance level for this trait, as discussed in Section 3.5. However, there was a very strong negative $r_{\mathrm{G}}$ between 1109 and DBHOB (i.e. larger trees are less susceptible to decay). Decay and heartwood extractive percentage were moderately strongly and negatively correlated to heartwood basic density for both 13851 and 7904 (i.e. denser wood and wood with a higher extractive content were less susceptible to decay). Heartwood basic density was weakly negatively correlated with heartwood proportion, DBHOB and bark thickness. Heartwood basic density was moderately genetically correlated with both mass loss (negatively) and extractive content (positively) for 13851 and 7904.

\subsection{NIR calibration}

Calibration models for the prediction of physicochemical properties from the NIR spectra of the wood meal are presented in Table 4. The extractives content of the cores 


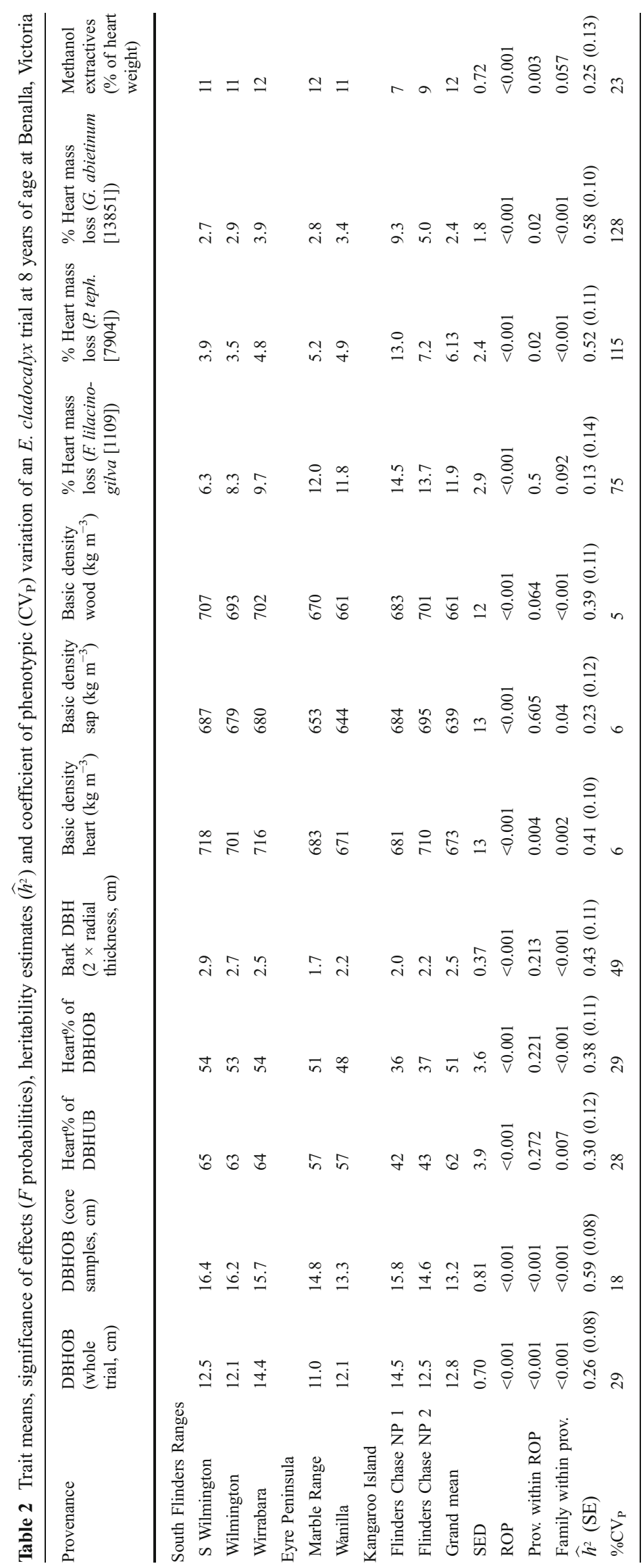


Table 3 Phenotypic $r_{\mathrm{p}}$ and genetic correlations $r_{\mathrm{G}}(\mathrm{SE})$ between pairs of traits in 8-year-old E. cladocalyx

\begin{tabular}{|c|c|c|c|c|c|c|c|c|}
\hline & Decay 13851 & Decay 7904 & Decay 1109 & $\begin{array}{l}\text { Basic density } \\
\text { of heartwood }\end{array}$ & Extractive & $\begin{array}{l}\text { Heartwood\% } \\
\text { of DBHUB }\end{array}$ & $\begin{array}{l}\text { Heartwood\% } \\
\text { of DBHOB }\end{array}$ & DBHOB \\
\hline \multicolumn{9}{|l|}{ Phenotypic correlation, $r_{\mathrm{p}}$} \\
\hline Decay 7904 & $0.27 * *$ & & & & & & & \\
\hline Decay 1109 & $0.38 * *$ & $0.45 * *$ & & & & & & \\
\hline Basic density of heartwood & $-0.30^{* *}$ & $-0.21 *$ & $-0.29 * *$ & & & & & \\
\hline Extractive & $-0.50 *$ & $-0.31 * *$ & $-0.23^{*}$ & $0.19^{*}$ & & & & \\
\hline Heartwood $\%$ of DBHUB & $-0.36^{*}$ & -0.15 & $-0.34 * *$ & $0.25 *$ & $0.41 * *$ & & & \\
\hline Heartwood $\%$ of DBHOB & $-0.32 *$ & -0.06 & $-0.28 * *$ & $0.23 *$ & $0.31 * *$ & $0.91 * *$ & & \\
\hline DBHOB & 0.12 & 0.00 & $-0.21 *$ & 0.08 & $-0.34 * *$ & 0.10 & 0.07 & \\
\hline Bark thickness & 0.00 & -0.15 & -0.12 & 0.03 & 0.07 & 0.09 & $-0.30 * *$ & $0.40 * *$ \\
\hline \multicolumn{9}{|l|}{ Genetic correlation, $r_{\mathrm{G}}$} \\
\hline Decay 7904 & $0.95(0.12)$ & & & & & & & \\
\hline Decay 1109 & $0.33(0.44)$ & $1.04(0.28)$ & & & & & & \\
\hline Basic density of heartwood & $-0.67(0.20)$ & $-0.54(0.14)$ & $0.09(0.46)$ & & & & & \\
\hline Extractive & $-0.61(0.27)$ & $-0.44(0.28)$ & $-0.14(0.55)$ & $0.20(0.31)$ & & & & \\
\hline Heartwood $\%$ of DBHUB & $-0.61(0.14)$ & $-0.78(0.10)$ & N.D. & $-0.19(0.33)$ & $-0.00(0.20)$ & & & \\
\hline Heartwood $\%$ of DBHOB & $-0.53(0.16)$ & $-0.70(0.12)$ & N.D. & $-0.11(0.29)$ & $-0.01(0.36)$ & $0.98(0.02)$ & & \\
\hline DBHOB & $0.15(0.24)$ & $-0.40(0.20)$ & $-1.02(0.27)$ & $-0.16(0.25)$ & $-0.42(0.26)$ & $0.50(0.21)$ & $0.44(0.21)$ & \\
\hline Bark thickness & $-0.20(0.27)$ & $-0.57(0.23)$ & $-0.21(0.46)$ & $-0.08(0.28)$ & $-0.19(0.33)$ & $-0.34(0.33)$ & $-0.54(0.24)$ & $0.39(0.21)$ \\
\hline
\end{tabular}

$N D$ not determined due to non-convergence of REML algorithm

$* * P<0.001, * P<0.05$ (phenotypic correlations significantly different from zero)

can be predicted from the NIR spectra of the ground wood. The absolute error of prediction is $\pm 0.009 \%$, which corresponds to a relative error of $8.8 \%$ of the mean extractives value. Whilst both first and second derivative spectra provided similar results, the second derivative spectra were used as they provided convergence of the model with fewer principal components.

The calibration of basic density for the heartwood was able to be determined at a modest level of accuracy $\left( \pm 31 \mathrm{~kg} \mathrm{~m}^{-3}\right)$.
Correlation of the NIR spectra with the decay data as per cent mass loss was only slightly successful for one of the decay fungi [1109] (F. lilacino-gilva) based on the coefficients of determination $\left(R^{2}\right)$ and the root mean square error of prediction (RMSEP; see Electronic supplementary material for calibration plot). Two approaches were modelled, one using each individual decay fungus as the response variable and one using the three decay fungi as a multivariate response. In both instances, the error in prediction of the

Table 4 Calibration statistics for NIR partial least squares (PLS-1) calibration models giving PCs, $R^{2}$ (coefficient of determination of calibration and validation), RMSECV and RMSEP

\begin{tabular}{|c|c|c|c|c|c|c|}
\hline & Treatment & No. of PCs/outliers & $R^{2}$ (calib.) & RMSECV (\%) & $R^{2}$ (valid.) & RMSEP (\%) \\
\hline Heartwood methanol extractives $(\%, w / w)$ & 2nd derivative & $4 / 0$ & 0.933 & 0.007 & 0.88 & 0.009 \\
\hline Density $\left(\mathrm{kg} \mathrm{m}^{-3}\right)$ & 2nd derivative & $3 / 3$ & 0.48 & 24 & 0.15 & 31 \\
\hline \multicolumn{7}{|l|}{ Decay (individual) } \\
\hline 1109 & 1st derivative & $5 / 4$ & 0.43 & 3.6 & 0.27 & 4.1 \\
\hline 1109 & 2nd derivative & $3 / 3$ & 0.46 & 3.6 & 0.28 & 4.2 \\
\hline 7904 & 2nd derivative & $2 / 1$ & 0.24 & 3.5 & 0.07 & 3.9 \\
\hline 13851 & 2nd derivative & $2 / 4$ & 0.44 & 3.9 & 0.32 & 4.3 \\
\hline \multicolumn{7}{|l|}{ Decay (combined) } \\
\hline 1109 & 2nd derivative & $4 / 2$ & 0.47 & 3.6 & 0.27 & 4.2 \\
\hline 7904 & 2nd derivative & $4 / 2$ & 0.19 & 3.9 & 0.08 & 4.1 \\
\hline 13851 & 2nd derivative & $4 / 2$ & 0.35 & 4.1 & 0.22 & 4.6 \\
\hline
\end{tabular}

$P C$ s principal components, RMSECV root mean square error of cross-validation, $R M S E P$ root mean square error of prediction 
mass loss for 1109 was $\pm 4.2 \%$ (or $38 \%$ of the mean). Whilst the coefficient of determination and error in prediction for $G$. abietinum was similar to that of 1109 for the individual calibration $\left(R^{2}=0.44\right.$, RMSEP $\left.=4.3 \%\right)$, the error as a percentage of the mean decay is $109 \%$. The calibration statistics for P. tephropora [7904] were similarly poor, with an $R^{2}$ of 0.34 and a RMSEP of $\pm 3.9 \%$ ( $68 \%$ of the mean).

\section{Discussion}

Growth and heartwood proportion analyses show that significant heartwood was present at breast height at 8 years (72 and $88 \mathrm{~mm}$ in the whole and core sample populations, respectively), to indicate that a round post of $75-\mathrm{mm}$ large-end heartwood diameter could probably be produced within 8 10 years from this site. Moreover, it would appear that heartwood proportion is a moderately heritable trait with a high $\mathrm{CV}$, and there is also a significant scope for provenancelevel selection. Similar findings have been made for $P$. sylvestris $\left(\widehat{h}^{2}=0.3-0.5\right.$; Ericsson and Fries 1999) and E. grandis $\left(\widehat{h}^{2}=0.39\right.$; dos Santos et al. 2004) heartwood. We did not find that $\mathrm{DBHOB}$ and heartwood proportion were strongly genetically correlated $\left(r_{\mathrm{G}}=0.44\right)$, a finding at odds with Paques (2001) who reported $r_{\mathrm{G}}=0.87-0.92$ between various Larix spp. radial growth and heartwood. The South Flinders provenances (particularly Wirrabara) would be the target of selection at the provenance level as they have both good diameter growth and a higher proportion of heartwood on average. Whilst selection for heartwood proportion would be an important trait for the production of small poles, it would be less so for later-rotation sawlog production as the proportion of sapwood to heartwood would be expected to decline significantly, and it is likely that the CVof heartwood proportion would decrease over time.

Significant genetic variation in basic density was found, the heartwood being denser than the sapwood and the Kangaroo Island and South Flinders Ranges ROP being significantly denser than the Eyre Peninsula. However, the range of difference is only approx. $20-30 \mathrm{~kg} \mathrm{~m}^{-3}$ around a grand mean of $660 \mathrm{~kg} \mathrm{~m}^{-3}\left(\mathrm{CV}_{\mathrm{P}}=6 \%\right)$, making all of the youngaged wood quite dense: the least dense Kangaroo Island material would still be too dense for pulp production for example. The prediction of this trait using NIR was only moderately successful $\left( \pm 31 \mathrm{kgm}^{-3}\right)$, a result similar to that of Schimleck et al. (2001). NIR would be insufficiently precise for resolving the small differences between genotypes. Genetic correlations between basic density and two of the fungal decay results (13851 and 7904) were negative and moderate. Yu et al. (2003) found a similar negative correlation for basic density and Gloeophyllum trabeum decay in P. glauca but, in reviewing the literature on several other softwood species, noted that both positive and negative phenotypic and genetic correlations between these traits have been reported.

The very good NIR prediction $\left(R^{2}=0.88\right)$ for methanol extractives makes it a quick and cost-effective method of assay, a result similar to that previously determined for $E$. globulus $\left(R^{2}=0.89\right.$; Poke et al. 2005). The overall extractive content $(12 \%)$ in E. cladocalyx is high compared with less durable species such as E. globulus (typically approx. 5\%, e.g. Poke et al. 2006). It is often stated that resistance to biodeterioration is a direct result of extractive content (e.g. Standards Australia 2005). This is supported by the moderately strong (and negative) genetic correlations between extractive content and biodeterioration from 13851 to 7904 and the correlation between predicted extractives and mass loss for 1109 (Table 3). The estimated heritability of methanol extractives was moderate at $0.25 \pm 0.13$ (c.f. $0.37 \pm 0.23$ in $E$. globulus; Poke et al. 2006), and $\mathrm{CV}_{\mathrm{P}}$ was also moderate. However, the variation among ROP and provenances was marked, and selection at this level would be an important first step in breeding programmes.

The heritability of resistance to fungal decay, based on the three chosen fungi, was estimated to be high, at least for two of the fungi $(7904,0.52 \pm 0.11 ; 13851,0.58 \pm 0.10)$, and there is also significant scope for improving this trait by provenance or ROP selection in all three. By comparison, Yu et al. (2003) estimated moderate $\widehat{h}^{2}=0.21$ and 0.27 for $P$. glauca decay resistance to brown and white rots, respectively. An interesting finding was the very strong negative genetic correlation between $\mathrm{DBHOB}$ and decay from 1109 and moderately strong correlation for 7904 . Bearing in mind that genetic parameter estimates for 1109 were generally of poor precision, with most of the variance at the provenance level, this phenomenon might be explained by the very aggressive attack of this fungus on core samples of small diameter. It is well known that the pith region of the heartwood is less resistant to decay than the outer heartwood (Hillis 1987). In preparing samples for decay testing from the 12-mm cores, outer heartwood was taken preferentially, but in small-sized trees, increasing proportions of inner heartwood were necessarily included. This may have contributed to the more rapid decay of the Kangaroo Island material as it tended to have a smaller heartwood core, though extractive content within that core, of which there was less on average, is also likely to have a bearing on decay rates.

NIR was not a successful tool for predicting decay, with $R^{2}$ in the validation populations only $0.07-0.32$ for the three fungi. Natural durability is a complex trait, resulting from wood physical as well as chemical properties (Hillis 1987). It is likely that NIR-predicted durability would be more precise in cases where more of the durability was attributable to the 
clearly NIR-predictable chemical substances, such as the extractives. However, as it stands, the NIR has the bestpredicted decay from 1109 which had $r_{\mathrm{G}}$ of only $-0.14 \pm 0.55$ between decay and methanol extractives and performed worst for 7904, which had $r_{\mathrm{G}}=-0.61 \pm 0.27$ for this pair of traits. It is disappointing that NIR was a poor predictor of decay because the soil jar technique is expensive, labour- and space-intensive, presenting a practical limit on the scale of studies that can be performed. All of the reviewed studies involving accelerated biodeterioration traits including our own have been on relatively small numbers of trees $(100$ 400 ) from very small samples of families or clones (20-50) nearly always sampled from a single site. Whilst this is adequate for identifying genetic variation and coarse estimation of variance components, larger studies would be needed in a later-stage breeding programme to provide precise and unbiased estimates of genetic parameters. Clearly, a low-cost predictive tool like NIR would be very useful if accurate. In contrast to our finding, Gierlinger et al. (2003) achieved $R^{2}$ of 0.84 and 0.94 with RMSEP $=0.08$ (both) for Coniophora puteana and Poria placenta decay of Larix spp., indicating that the technique can be highly useful in at least some conifers.

A very encouraging finding is that the South Flinders Ranges provenances and families within this ROP tended to have the highest heartwood proportion, the strongest resistance to decay and higher extractive content than the Kangaroo Island provenance material tested. This has important implications for breeding programmes for this species. If naturally durable and/or increased young-aged heartwood production is a priority, it would be advantageous to screen the populations for some of the traits studied here or, as a lower cost alternative, reduce the proportion of Kangaroo Island-origin individuals in breeding populations.

\section{Conclusion}

This study has shown that there is considerable genetic variation in natural durability-related wood properties, including heartwood/sapwood ratio, extractive content and resistance to biodeterioration (soil jar test) in E. cladocalyx. The use of NIR for the determination of heartwood extractives was highly effective, but the technique was not sufficiently precise for an accurate determination of fungal mass loss. Strong variation among populations indicates that selection of the correct provenances, particularly those from the South Flinders Ranges region, would result in a significant genetic improvement. With the caveat that heritability estimates here are based on a relatively small sample of families within provenances from a single site and that there was bias towards sampling of larger trees and families, there would also appear to be good prospects for genetic improvement through recurrent selection and breeding within populations. Though precision of estimation was in many cases low, unfavourable genetic correlations between growth and durability traits are not indicated. It has previously been observed that there is considerable within-species variation in natural durability in Eucalyptus, and this study indicated that a significant proportion of the variation may be genetic.

Acknowledgements We would like to acknowledge the useful comments of two anonymous reviewers on a draft of the paper. Paul Macdonell, Luke Bulkeley, Nick Ebdon, Brioni Brammall and Jenny Carr assisted with field and laboratory work. The study was jointly funded by Rural Industries Research and Development Corporation and CSIRO.

\section{References}

Bailleres H, Davrieux F, Ham-Pichavant F (2002) Near infrared analysis as a tool for rapid screening of some major wood characteristics in a Eucalyptus breeding program. Ann For Sci 59:479-490

Beckman CH (2000) Phenolic-storing cells: keys to programmed cell death and periderm formation in wilt disease resistance and in general defence responses in plants? Physiol Mol Plant Pathol $57: 101-110$

Bush D, Kain D, Matheson C, Kanowski P (2011) Marker-based adjustment of the additive relationship matrix for estimation of genetic parameters - an example using Eucalyptus cladocalyx. Tree Genet Genomes 7:23-35

Callister A, Bush DJ, Collins S, Davis W (2008) Prospects for genetic improvement of Eucalyptus cladocalyx in Western Australia. New Zeal J For Sci 38:211-226

dos Santos PET, Geraldi IO, Garcia JN (2004) Estimates of genetic parameters of wood traits for sawn timber production in Eucalyptus grandis. Genet Mol Biol 27:567-573

Ericsson T, Fries A (1999) High heritability for heartwood in north Swedish Scots pine. Theor Appl Genet 98:732-735

Gierlinger N, Jacques D, Schwanninger M, Wimmer R, Hinterstoisser B, Paques LE (2003) Rapid prediction of natural durability of larch heartwood using Fourier transform near-infrared spectroscopy. Can J For Res 33(9):1727-1736

Gierlinger N, Jacques D, Schwanninger M, Wimmer R, Paques LE (2004) Heartwood extractives and lignin content of different larch species (Larix spp.) and relationships to brown-rot decayresistance. Trees 18:230-236

Harwood CE, Bush DJ, Butcher T, Bird R, Henson ML, Lott R, Shaw $S$ (2007) Achievements in forest tree genetic improvement in Australia and New Zealand. 4. Tree improvement for low-rainfall farm forestry. Aust For 70:23-27

Hillis WE (1987) Heartwood and tree exudates. Springer, Berlin, $268 \mathrm{pp}$

Kjaer ED, Kajornsrichon S, Lauridsen EB (1999) Heartwood, calcium and silica content in five provenances of teak (Tectona grandis L.). Silvae Genet 48:1-3

Lorenzo D, Troya M, Prieto M, Baso C, Touza M (2007) Study of the natural durability of Spanish Eucalyptus globulus wood. The International Research Group on Wood Preservation IRG Document No. IRG/WP 07-10617

McDonald MW, Rawlings M, Butcher PA, Bell JC (2003) Regional divergence and inbreeding in Eucalyptus cladocalyx (Myrtaceae). Aust J Bot 51:393-403 
Mohareb A, Sirmah P, Desharnais L, Dumarçay S, Pétrissans M, Gérardin P (2010) Effect of extractives on conferred and natural durability of Cupressus lusitanica heartwood. Ann For Sci 67 (5):504

Mora F, Gleadow R, Perret S, Scapim CA (2009) Genetic variation for early flowering, survival and growth in sugar gum (Eucalyptus cladocalyx F. Muell) in southern Atacama Desert. Euphytica 169:335-344

Mosedale JR, Charrier B, Janin G (1996) Genetic control of wood colour, density and heartwood ellagitannin concentration in European oak (Quercus petraea and Q. robur). Forestry 69:111-124

Nicholls JWP, Matheson AC (1980) Variation in wood characteristics in thinnings from a field trial of Eucalyptus obliqua. Aust For Res 10:239-247

Palanti S, Susco D, Feci E (2010) Natural durability of eucalypt from Italian plantations against fungi and cerambicid Trichoferus holosericeus Rossi. Eur J Wood Wood Prod 68:59-62

Paques LE (2001) Genetic control of heartwood content in larch. Silvae Genet 50:69-75

Poke FS, Wright JK, Raymond CA (2005) Predicting extractives and lignin contents in Eucalyptus globulus using near infrared reflectance analysis. J Wood Chem Technol 24:55-67

Poke FS, Potts BM, Vaillancourt RE, Raymond CA (2006) Genetic parameters for lignin, extractives and decay in Eucalyptus globulus. Ann For Sci 63:813-821
Rudman P (1966) Durability in the genus Eucalyptus. Aust For 28:242-257

Schimleck LR, Evans R, Ilic J (2001) Estimation of Eucalyptus delegatensis wood properties by near infrared spectroscopy. Can J For Res 31:1671-1675

Schmidtling RC, Amburgey TL (1982) Genetic variation in decay susceptibility and its relationship to growth and specific gravity in loblolly pine. Holzforschung 36:159-161

Standards Australia (2003) Methods of test for pulp and paper: Method 012s - organic solvent extractives in wood, pulp and paper. Standards Australia, Homebush, NSW, p 12

Standards Australia (2005) Timber-natural durability ratings. AS 5604-2005. Standards Australia, Homebush, New South Wales

TAPPI (1989) Basic density and moisture content of pulpwood. TAPPI no. T258 om-98

Washusen R, Ades P, Evans R, Ilic J, Vinden P (2001) Relationships between density, shrinkage, extractives content and microfibril angle in tension wood from three provenances of 10-year-old Eucalyptus globulus Labill. Holzforschung 55:176-182

Wong AHH, Wilkes J, Heather WA (1983) Influence of wood density and extractive content on the decay of the heartwood of Eucalyptus delegatensis R.T. Baker. J Inst Wood Sci 54:261-263

Yu Q, Yang DQ, Zhang SY, Beaulieu J, Duchesne I (2003) Genetic variation in decay resistance and its correlation to wood density and growth in white spruce. Can J For Res 33:2177-2183 